\title{
Characterization and analysis of the mango supply chain in San Cristóbal de la Barranca, Jalisco
}

\section{Caracterización y análisis de la cadena de suministro del mango de San Cristóbal de la Barranca, Jalisco}

\author{
ROMERO-ROMERO, Yair†*, VÁZQUEZ-ELORZA, Ariel and SÁNCHEZ-GÓMEZ, Julia* \\ Consejo Nacional de Ciencia y Tecnología (CONACYT)- Centro de Investigación y Asistencia en Tecnología y Diseño del \\ Estado de Jalisco (CIATEJ).
}

ID $1^{\text {st }}$ Author: Yair, Romero-Romero / ORC ID: 0000-0002-7779-4211, Researcher ID Thomson: F-1649-2019, CVU CONACYT ID: 239572

ID $1^{\text {st }}$ Co-author: Ariel, Vázquez-Elorza / ORC ID: 0000-0002-6710-8935, CVU CONACYT ID: 169076

ID $2^{\text {nd }}$ Co-author: Julia, Sanchez-Gómez / ORC ID: 0000-0001-5648-8920, CVU CONACYT ID: 375361

\begin{abstract}
The little development and disruption of in agri-food supply chains are important factors that prevent the growth of small Mexican producers, being the link with the lowest income of the entire chain and in which there are the greatest injustices. The objective of this research work is to map and identify the links the supply chain of the mango barranqueño; and benchmarked with the Tommy Atkins chain. The methodology used consisted of three steps: 1) Data analysis of the Barranco mango, 2) Mapping the supply chain of the mango barranqueño and Tommy Atkins and, as well as their relationships, and 3) Compare of supply chains to analyze the links that could be developed and improve in the supply chain of the mango barranqueño. The contribution of this work is the first approach for the analysis and improvement of the supply chain management of small producers of the barranqueño mango, in order to strengthen short sustainable supply chains.
\end{abstract}

Supply chain management, Small producers, Sustainable chains

\section{Resumen}

El escaso desarrollo y la disrupción de las cadenas de suministro agroalimentarias son factores importantes que impiden el crecimiento de los pequeños productores mexicanos, siendo estos el eslabón con menor ingreso de toda la cadena y en el que se presentan mayores injusticias. El objetivo de este trabajo de investigación es mapear e identificar los eslabones de la cadena de suministro del mango barranqueño; y realizar un benchmarking con la cadena del mango Tommy Atkins. La metodología utilizada constó de tres etapas: 1) Análisis de datos del mango barranqueño, 2) Mapeo de la cadena de suministro del mango barranqueño y Tommy Atkins y, así como sus relaciones, y 3) Comparar las cadenas de suministro para analizar los vínculos que se podrían desarrollar y mejorar en la cadena de suministro del mango barranqueño. La contribución de este trabajo es un primer acercamiento para el análisis y mejora de la gestión de la cadena de suministro de los pequeños productores del mango barranqueño, con el fin de fortalecer cadenas sostenibles cortas.

Gestión de la cadena de suministro, Pequeños productores, Cadenas sostenibles

Citation: ROMERO-ROMERO, Yair, VÁZQUEZ-ELORZA, Ariel and SÁNCHEZ-GÓMEZ, Julia. Characterization and analysis of the mango supply chain in San Cristóbal de la Barranca, Jalisco. Journal of Environmental Sciences and Natural Resources. 2021. 7-19:12-18.

\footnotetext{
* Correspondence of the Author (E-mail: yromero@ ciatej.mx)

$\dagger$ Researcher contributing first author.
} 


\section{Introduction}

For decades the Mexican countryside has been greatly impacted in the social, environmental and economic spheres. In the social sphere, the migration of the rural population to the cities has caused a change in the social structure, namely, in 1900 the rural population was 9.8 million inhabitants and represented $72.1 \%$ of the Mexican population. This percentage decreased to $23 \%$ in 2015 , which is why $77 \%$ of the population is currently concentrated in cities (INEGI, 2020; SERMARNAT, 2016). Of the 27.5 million people who currently live-in rural areas, only 5.5 million work in the fields, and of these, $56 \%$ are farmers with an average age of 42.7 years (Hablemos de Campo, 2018). In addition, it is worth mentioning that the 36 million Mexican migrants who reside in the United States work mainly in the agricultural and construction sectors (Sulbarán, 2019). This migration to cities and other countries has caused a shortage of labor for rural activities (Ríos, 2017). Another factor that affects the field is the environmental one, mainly due to climate change, which is defined as "the variation in climate attributed directly or indirectly to human activity that alters the composition of the global atmosphere and adds to the natural variability of the observed climate. during comparable periods" (CEDRSSA, 2019).

Agricultural products, mainly those that are in the open air, are vulnerable to climate change due to its negative effect on the vegetative cycle, due to the increase or decrease in temperature and humidity (droughts, floods and frosts). This causes volatility in food prices and affects the economic factor.

Small-scale farmers face high input costs and high transport costs (Leonardo et al., 2004), coupled with this, low modernization and climate change lead to a decrease in production and consequently, profitability for the producer. . In addition, most markets have a reduced opening for the products of small farmers (Jaller, 2010), pushing them to sell their production to collectors. These establish the price of production, so that most of the time, the peasant only recovers what he has invested without a return so that his productive unit is sustainable over time. This has caused some producers to abandon their harvest in the field, or to dedicate themselves only to planting and harvesting products for their own consumption.
There are rural producers who have sought alternatives to invest in their fields, through financing, but since they do not exist or deny them credit in institutions governed by the National Banking and Securities Commission (CNBV) and Banco de México (BM), they have fallen into markets informal financial institutions in which they pay very high interest rates (Norton, 2010).

The products of the field that are being harmed by the negative externalities of these three factors (social, environmental, and economic) are many and affect small producers to a greater extent. This is the case of the Barranca mango, considered as Creole mango, produced in the bowels of the Barranca de San Cristóbal that surrounds the Santiago River (Government of the State of Jalisco, 2020), on the north side of the Metropolitan Area of Guadalajara, and that is harvested during the season of April and June.

According to the local inhabitants of San Cristóbal de la Barranca, the mangoes have a sweeter taste and the ones with the greatest flavor are the Barranco mangoes called "swollen", being those that ripen on the tree. Once they reach maturity these mangoes fall under their own weight (also locally called pulled mangoes), due to the blow of the fall most of them are bruised, which reduces their quality and restricts the bargaining power of the small ones. producers in the market, as a result they are used mainly for self-consumption.

The main market for cut mangoes is developed on the side or near the highway that leads from Guadalajara to Zacatecas, the marketing and logistics channels are limited, a low quantity of mangoes reach other local markets and on wheels. Generally, the mangoes are transported by the producer in small quantities, which increases the cost of transportation, in addition, most of the markets they reach stipulate the purchase prices of the product (Calderón, Roark, Urrutia, Paravié, \& Rohvein, 2017) which results in lower income for the producer. Under this scenario, it is no longer enough to only improve the operations and internal cultural activities of agricultural producers, but rather, it is necessary to go beyond their borders and initiate relations of exchange of information, materials, and resources in the most appropriate way. integrated (Calderón et al., 2017).

ROMERO-ROMERO, Yair, VÁZQUEZ-ELORZA, Ariel and SÁNCHEZ-GÓMEZ, Julia. Characterization and analysis of the mango supply chain in San Cristóbal de la Barranca, Jalisco. Journal of Environmental Sciences and Natural Resources. 2021 
One way to achieve this is through the design and management of the supply chain, in which all operations carried out on the product are referenced and monitored, from raw materials to the end customer (Ballou, 2004). The reason is that today companies no longer compete for their internal efficiency, but for the efficiency of the supply chain to which they belong (Calderón et al., 2017).

The objective of this research is to map and identify the links in the Barranco mango supply chain; and benchmarking with the Tommy Atkins handle chain. The article is divided into the following sections: 1) Materials and methods where the methodology followed to achieve the desired results is described. 2) Background, in this section the main terms used throughout the article are defined. 3) Development and results, the mapping of the two supply chains of the Barranco mango and the Tommy Atkins mango are described. Subsequently, the conclusions are made known.

\section{Materials and methods}

The research was quantitative exploratory in nature (Hernández Sampieri \& Mendoza Torres, 2018), which was useful to obtain information on the characteristics and processes of the Barranco mango supply chain. The methodology considers three stages (Figure 1).

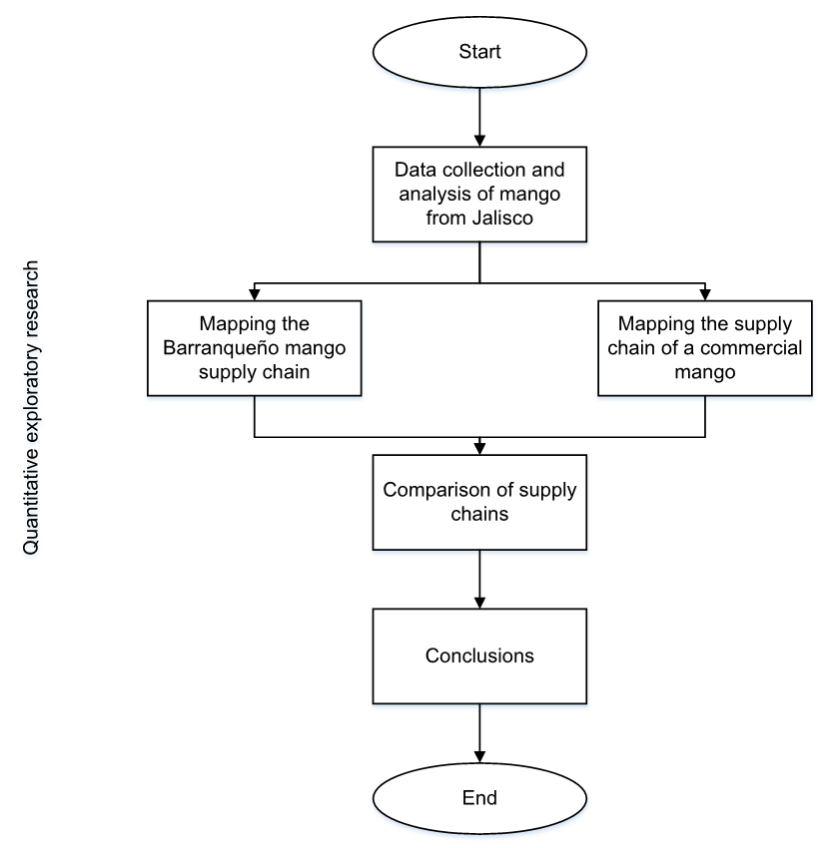

Figure 1 Methodology: Quantitative exploratory research Source: Own elaboration
Stage 1, data collection and analysis of the Barranco mango. There is a large volume of information about the agricultural sector on electronic pages of the Internet and, instruments, methodologies and / or techniques are required that are capable of processing them in volume, speed and quality (Gutiérrez-Pulido \& VaraSalazar, 2013). In this first stage, to analyze information on mango from San Cristóbal de la Barranca and commercial mango (Tommy Atkins), descriptive statistics were used, which is a set of numerical and graphic techniques to obtain, collect, process, summarize and present data (Rustom, 2012). In this case, data referring to mango production, characteristics of each of the links in the supply chain, quality indices, among others.

Stage 2, supply chain mapping. Supply Chain Management (GCS) aims to ensure the provision of safe and healthy products that are fully traceable from "farm to fork" (Moxham, 2004), however, Chains of Food Supply (CSA) operate in a complex environment where there are conflicts of interest, paradoxes, power struggles, uncertainties, risk elements, injustices, in addition to the fact that the Mexican countryside is one of those with the largest number of intermediaries, increasing the cost of products up to $630 \%$ (Chávez, 2014). Likewise, this environment is dynamic (climate, inflation), and requires taking into consideration variables of great importance such as time and critical care (integrity is important in food products due to their perishability and handling) (Gustafsson $e t$ al., 2006).

Consequently, in this second stage of exploratory research, supply chain mapping was applied, a tool that allows a panoramic view of the entire process chain, how actions are developed and links with other links (Ballou, 2004; Chopra \& Meindl, 2008) and is useful to identify activities or processes that add value and those that should be omitted.

Stage 3, comparison of the chains. Finally, a comparison was made of the supply chains for Barranco mango and Tommy Atkins mango, both produced in Jalisco. The second, a chain with greater development, served to observe the challenges and opportunities of the Barranco mango chain. 


\section{Background}

The supply chain represents a series of activities that are important for any agricultural production unit. Generally, small producers do not have the capacities and infrastructure to achieve high levels of competitiveness. According to Ballou (2004), the supply chain "is made up of processes that range from the purchase of raw materials to the delivery of the final product, including suppliers, production, warehouses, distribution, supply and customers". The articulation of the chain and implementing an order of intervention of the participating actors and processes can increase the profits of the entire chain in the short to medium term (Anaya-Dyck, HernándezOñate, Tafolla-Arellano, Báez-Sañudo, Gutiérrez-Martínez, \& Tiznado-Hernández, 2021).

The Barranco mango is a product considered as a Creole fruit, in contrast, the Tommy Atkins mango is a commercial variety and presents an organized logistics chain with national and international marketing scope. In other words, the supply, production, and distribution processes of Barranco mango are far from reaching high standards of competitiveness. In this sense, Anand \& Kodali (2008, p. 258) point out that there are companies that strive to be faster, better and cheaper than others that are in the competition, so Benchmarking is a good tool to have a thermometer that helps analyze and compare the innovations and improvements implemented in the productive sectors. In this way, it is relevant that the organizations and economic units of the Barranco mango begin with the knowledge of other varieties of the fruit that are succeeding not only in the production but also in the sale and transformation of the same.

\section{Development, Results and Discussion}

The supply chain is a poorly developed issue for small producers in the agricultural sector, as is the case of the Barranco mango producers, where it was identified that, in the best of cases, they are part of a chain with informal links between its links. . This mainly generates loss of the product, high transport costs and lack of markets. As is the situation of the majority of the small mango producers in San Cristóbal de la Barranca.

\section{Barranqueño mango}

The Barranco mango supply chain is mainly made up of four links: supply, production, retailers, and customers. This structure turns out to be relatively less complex than the chain of a mango variety that has an industrial or export process in Jalisco. Among the actors that make up the links in the Barranco mango chain are (Figure 2):

Suppliers: the labor force is made up of around 10 people for cutting in an orchard, 3 haulers, 2 packers, suppliers of boxes and sacks for harvesting and packing the fruit. On the other hand, there are those who offer the transport service to transport mangoes to urban areas (metropolitan) and those who move damaged mangoes, which are not used for sale but for animal feed.

Production units: according to the agricultural census prepared by INEGI, in the municipality of San Cristóbal de la Barranca there are 29 territorial units of mango production, of which 15 are seasonal and 14 have irrigation conditions. The total area amounts to 3,502.63 ha.

Retail: there is a small number of actors dedicated to retail sales, generally they come from other locations, given that they have the capacity to mobilize and transport high volumes of the fruit. Most orchards have plantations that can be more than 100 years old; In other words, there is a low rotation and production of new plants, although some governmental efforts and producers can be found that have planted new plants in their fruit orchards. In this way, in the medium term the integration of other actors to the chain for soil analysis, innovation, transfer of technical knowledge and value addition will be required, to increase the income of the families that produce the fruit.

Market: the point of sale of the Barranco mango is located mainly in the shops on wheels and municipal markets. The low volumes marketed by the economic productive units (small scale) represent a real challenge to cover the large volumes demanded by the large selfservice stores. 
It is important to point out that some Barranco mango producing families are beginning activities to add value through the production of boxes, sweets and other products that include the raw material. In the field work, at least three units were identified, mainly where women producers collaborate (personal communication).

\section{Tommy Atkins handle}

As more actors are added to a supply chain, a complexity begins to develop in the relationships between the actors. In this case, the Tommy Atkins mango chain includes more specialized actors, such as technicians, input suppliers, intermediaries, packaging, industry, chains, and logistics, among others (Figure 3).

According to the Mango Product System Master Plan (SAGARPA, 2012) in the state of Jalisco, the distribution of the actors that participate in the supply chain is distributed as shown in table 1:

\begin{tabular}{|l|r|}
\hline \multicolumn{1}{|c|}{ Actors and activities } & Quantity \\
\hline Freezing fruits and vegetables & 4 \\
\hline Dehydration of fruits and vegetables & 11 \\
\hline $\begin{array}{l}\text { Preservation of fruits and vegetables by } \\
\text { processes other than freezing and } \\
\text { dehydration }\end{array}$ & 32 \\
\hline $\begin{array}{l}\text { Manufacture of non-electronic equipment } \\
\text { for medical, dental and laboratory use }\end{array}$ & 94 \\
\hline Wholesale of fresh fruits and vegetables & 778 \\
\hline Wholesale of canned food & 20 \\
\hline Retail trade of fresh fruits and vegetables & 5,510 \\
\hline Retail trade of other foods & 1,889 \\
\hline
\end{tabular}

Table 1 Actors involved in the mango supply chain in Jalisco

Source: Own elaboration with SAGARPA data (2012)

The mango supply chain represents a direct workforce of 8,338 people in the state of Jalisco, which includes $40 \%$ of the production value of the Atkins variety and $14 \%$ of Creole. Most of the labor force is concentrated in economic units of 0 to 5 people and 6 to 10 people. In this context, it is essential to strengthen related small companies through the design and implementation of public policies to increase competitiveness (INEGI, 2019).

\begin{tabular}{|l|r|}
\multicolumn{1}{c}{$\begin{array}{c}\text { Categories according to } \\
\text { number of workers }\end{array}$} & $\begin{array}{c}\text { Number of } \\
\text { economic units }\end{array}$ \\
\hline 0 to 5 people & 7,374 \\
\hline 101 to 250 people & 12 \\
\hline 11 to 30 people & 236 \\
\hline 251 and more people & 7 \\
\hline 31 to 50 people & 47 \\
\hline 51 to 100 people & 17 \\
\hline 6 to 10 people & 645 \\
\hline Grand Total & 8338 \\
\hline
\end{tabular}

Table 2 Number of economic units according to the number of workers

Source: Own elaboration with data from INEGI (2019)

\section{Conclusions}

The production of Barranco mango in the study location faces a problem that includes not only technical-productive aspects, but also those that involve the relations between the producer and his market.

An important point identified is that the small producers of Barranco mango have a disintegrated production chain, that is, they lack organization in their activities of primary production, chains, productive economic systems. This brings as consequences for the producer high levels of transaction costs and a reduced participation in the added value of the product. It is important to point out that the integration of chains is vital to increase marketing conditions and margins. In addition, having informal links with other members of the chain has a direct impact on the benefits that can be generated.

The lack of formal connections with the market introduces uncertainty about obtaining income for the producer. Therefore, developing strong marketing channels represents a major challenge.

The development of the Barranco mango production chain must be based on the study of what happens with other mango varieties, in order to find models that can be implemented. However, it is necessary to consider that other mango chains with greater development face other challenges, such as dependence on intermediaries, derived from their isolation conditions. These aspects must be taken into account in the design of an adequate strategy for Barranco mango producers. 


\section{Annexes}

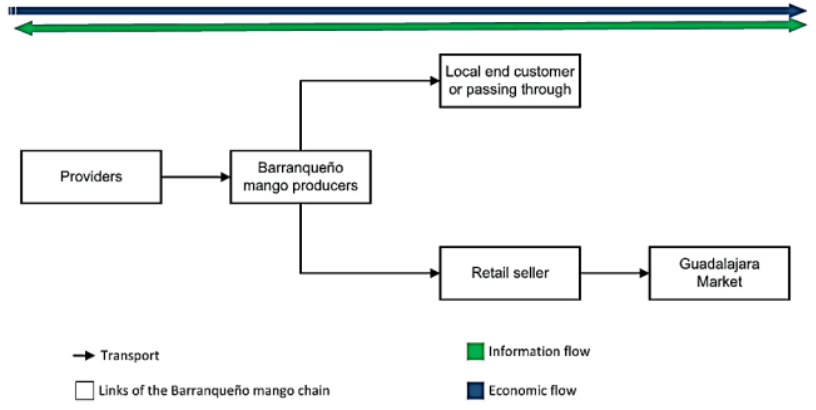

Figure 2 Barranco mango supply chain Source: Own elaboration

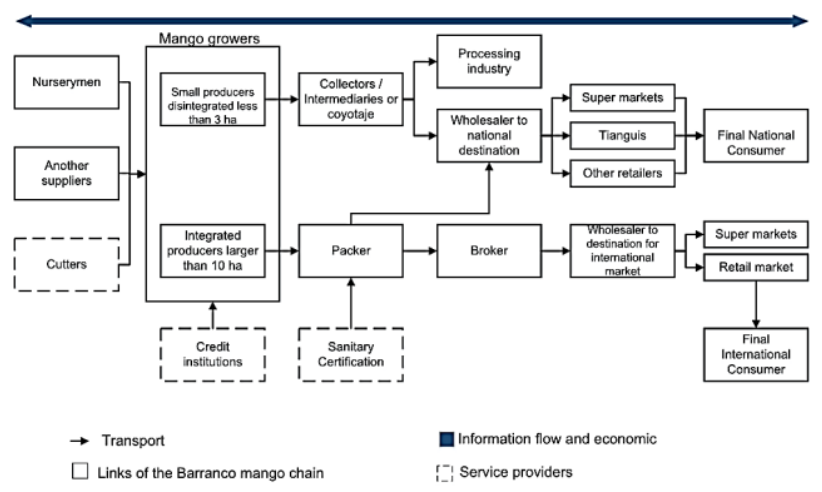

Figure 3 Tommy Atkins Mango Supply Chain Source: Own elaboration

\section{References}

Anaya-Dyck, J. M., Hernández-Oñate, M. Á., Tafolla-Arellano, J. C., Báez-Sañudo, R., Gutiérrez-Martínez, P., \& Tiznado-Hernández, M. E. (2021). La cadena productiva de guanábana: una opción para el desarrollo económico en Compostela, Nayarit. Estudios Sociales. Revista de Alimentación Contemporánea y Desarrollo Regional, 31(57), 1-34. https://doi.org/10.24836/es.v31i57.1048

Anand, G., \& Kodali, R. (2008). Benchmarking the benchmarking models. Benchmarking: An International Journal, 15 (3), 257-291. https://doi.org/10.1108/14635770810876593

Ballou, H. (2004). Logística Administración De La Cadena de Suministro. México: Pearson Educación.

Calderón M.A., Roark, G., Urrutia, S., Paravié, D., \& Rohvein, C. (2017). Metodología para la clasificación y diagnóstico de cadenas de suministro. Revista Ciencias Estratégicas, 25(38), 279-298. ISSN: 1794-8347.
CEDRSSA. (2019). El Cambio climático y el sector agropecuario en México. Recovered from: http://www.cedrssa.gob.mx/files/b/13/12El\%20c ambio\%20clim\%C3\%A1tico.pdf

Chávez, H. (11 de septiembre de 2014). Alimentos son hasta $630 \%$ más caros por intermediarios. El Financiero. Recovered from: https://www.elfinanciero.com.mx/economia/ali mentos-son-hasta-630-mas-caros-porintermediarios/

Chopra, S., \& Meindl, P. (2008). Administración de la cadena de suministro. Estrategia, planeación y operación. México: Pearson

Gobierno del estado de Jalisco. (2020). San Cristóbal de la Barranca. México: Jalisco Gobierno del estado. Recovered from: https://www.jalisco.gob.mx/es/jalisco/municipio s/san-cristobal-de-la-barranca

Gustafsson, K., Jönson, G., Smith, D., \& Sparks, L. (2006). Retailling Logistics \& Fresh Food Packaging. London and Philadelphia: koganpage. Recovered from: https://www.academia.edu/4506847/Retailing_1 ogistics_and_fresh_food_packaging

Gutiérrez-Pulido, H., \& Vara-Salazar R. (2013). Control Estadístico de la calidad Seis Sigma. México: McGraw-Hill. Recovered from: https://www.academia.edu/16455512/Control_E stad\%C3\%ADstico_de_la_Calidad_y_Seis_Sig ma_3ed

Hablemos de Campo. (15 de mayo de 2018). ¿Quiénes trabajan en el campo mexicano? Recovered from: https://www.hablemosdelcampo.com/quienestrabajan-en-el-campo-mexicano/

Hernández Sampieri, R., \& Mendoza Torres, C. P. (2018). Metodología de la investigación: las tres rutas cuantitativa, cualitativa y mixta. México: McGraw-Hill.

INEGI. (2019). Encuesta Nacional Agropecuaria 2019. México: Instituto Nacional de Estadística y Geografía. Recovered from: https://www.inegi.org.mx/programas/ena/2019/

INEGI. (2020). Población rural y urbana. México: Instituto Nacional de Estadística y Geografía. Recovered from: https://www.inegi.org.mx/temas/estructura/ 
Jaller, S. (2010). Foro nacional de vinculación de los pequeños productores al mercado. Recovered from: http://www.fao.org/3/as343s/as343s.pdf

De León, L.F., De León, E. F., Catalano, J. A., Rodríguez, D., Neira, E., \& Cuevas, R. (2004). Transporte rural de productos alimenticios en América Latina y el Caribe. Recovered from: http://www.fao.org/3/y5711s/y5711s.pdf

Moxham, C. (2004). Food Supply Chain Management. In International Journal of Operations \& Production Management, 24 (10) 1079-1080.

https://doi.org/10.1108/01443570410558085

Norton, R. D. (2010). Política del desarrollo agrícola: Conceptos y principios. Roma, Italia: Organización de las Naciones Unidas para la Alimentación y la Agricultura. Recovered from: http://www.fao.org/3/y5673s/y5673s00.htm

Ríos,V.M. (17 de febrero de 2017). Escasez de mano de obra, posible amenaza para productores mexicanos. Hortalizas. Recovered from: https://www.hortalizas.com/miscelaneos/laposible-escacez-de-la-mano-de-obra-puede-otraamenaza-para-los-agricultores/

Rustom J. A. (2012). Estadística Descriptiva, Probabilidad e Inferencia. Una visión conceptual aplicada. Santiago de Chile: Universidad de Chile. Recovered from: http://repositorio.uchile.cl/bitstream/handle/225 0/120284/Rustom_Antonio_Estadistica_descript iva.pdf? sequence $=1$

SAGARPA. (2012). Plan Rector Sistema Producto Mango. Recovered from: https://issuu.com/heribertohernandez5/docs/plan _rector_jalisco

SERMARNAT. (2016). Estadísticas históricas de México. Recovered from: https://apps1.semarnat.gob.mx:8443/dgeia/indic adores_verdes18/indicadores/archivos/pdf/01_c ontexto/indicadores/CSE_1.1.2.pdf

Sulbarán, L. (6 de febrero de 2019). Mexicanos en Estados Unidos: las cifras que muestran su verdadero poder económico. BBC News Mundo. Recovered from: https://www.bbc.com/mundo/noticiasinternacional-46705825

(SERMARNAT, 2016). 